\title{
Rate-Reducing Resistance to Ascochyta Blight in Chickpeas
}

M. V. REDDY, Senior Plant Pathologist, Legumes Program, International Crops Research Institute for the SemiArid Tropics (ICRISAT), Patancheru. Andhra Pradesh 502 324. India, and K. B. SINGH. Principal Chickpea Breeder, ICRISAT-ICARDA Chickpea Project, International Center for Agricultural Research in the Dry Areas (ICARDA), P.O. Box 5466, Aleppo, Syria

\begin{abstract}
Reddy, M. V., and Singh, K. B. 1993. Rate-reducing resistance to Ascochyta bligh! in chickpeas Plant Dis. 77:231-233.

In a field experiment conducted at the International ('enter for Agricultural Research in the Dry Areas in Syria during 198283,198384 , and 198586 crop years, disease progress of Ascochyta blight was studied in chickpea cultivars II.C 464, IIC 482, and II.C 3279. On the basis of apparent infection rate (r). ILC $482(r=0.160 .29)$ and II.C $3279(r-0.030 .23)$ were identified as cultivars with rate-reducing resistance in comparison with the susceptible cultivar ILC $464(r-0.240 .68)$. Average grain yield for three seasons was nearly $1,800 \mathrm{~kg} \cdot \mathrm{ha}$ for ILC. 482 and II.C 3279 but only $100 \mathrm{~kg}$ for II. ( 464 .
\end{abstract}

Ascochyta blight (caused by Asco(hyta rabiei (Pass.) Labrousse) - an important disease of chickpea (Cicer arietinum L.) in India, Pakistan, western Asia, North Africa, and southern Furope assumes epidemic proportions in seasons with rainfall of $150 \mathrm{~mm}$ or more (4). Without blight, the rain would enhance chickpea yields substantialiy. During dry seasons, blight is not severe, but the grain yield is reduced by drought stress in rainfed production. Thus, management of Ascochyta blight is essential for increasing and stabilizing chickpea yields.

In the Mediterranean region, chickpeas are traditionally sown at the beginning of spring (March-April), but the yicld of chickpea can be increased by $50 \%$ by sowing in winter (early December) provided that Ascochyta blight is controlled (2). Ascochyta blight is severe in the winter season because of cool and wet weather (10)

Management of Ascochyta blight can be achieved with fungicides and resistant cultivars. Several protective fungicides have been identified, but chemical control is neither practical nor economical, because more than six fungicide applications per season are needed to control the disease in susceptible cultivars (8). Development of cultivars with resistance to Ascochyta blight has not been successful due to lack of higher and stable resistance $(5,11)$. With the appearance of new races of the pathogen, there is a continuous need for new disease-resistant cultivars (11). There are several reports of resistant chickpea genotypes, but the type of resistance is unknown (11). While

A joint contribution from ICRISAT and ICARDA and submitted as ICRISAT Journal Aricle no 1240.

Accepted for publication 21 August 1992

1993 The American Phytopathological Society evaluating the world collection of chick pea germ plasm for resistance to Ascochyta blight at the International (enter for Agricultural Research in the Dry Areas (ICARDA), we observed a few accessions with low levels of disease during epidemics that killed susceptible cultivars (7).

Because of the variability of $A$. rabiet and ineffectiveness of host resistance, we decided to study disease progress and yield in cultivars with low blight severity Chick pea cultivars with reduced rates of disease progress may improve the management of Ascochyta blight.

\section{MATERIALS AND METHODS}

Iwo ICARDA cultivars (ILC 482 and II.C 3279) with a low final severity of Ascochyta blight and the susceptible cultivar II.C 464 were studied (7). II.C 464 is a highly susceptible, large-seeded (40) g per 100 seeds) kabuli cultivar. IIC 482 is a moderately suceptible kabuli cultivar with medium seed size $(30 \mathrm{~g}$ per 100 seeds). ILC 3279 is a moderately resistant intermediate-type cultivar with small pea-shaped, orange seed $(28 \mathrm{~g}$ per 100 seeds). The cultivars were sown in field plots $(10 \times 100 \mathrm{~m}$ each $)$ in the first week of December of 1982, 1983, 1984, and 1985. The experimental design was a randomized block with three replications. Spacing between rows was $30 \mathrm{~cm}$ and within rows $10 \mathrm{~cm}$. One month after sowing, plants in the plots were inoculated by scattering infested chickpea debris (7). During the 1982-83 season, the debris collected from susceptible cultivar ILC 1929 was used. In the subsequent three seasons, debris from a mixture of test entries was used. The experimental crops were grown under rainfed conditions. Temperature and relative humidity were recorded using a hygrothermograph (10).

Starting from the onset of symptoms, incidence and severity of Ascochyta blight were recorded at weekly intervals throughout the crop season. The interval between some observations during 1982 8.3 was longer (19 days), and only cight observations wete made. During the 1983 84 and 1985 86 crop seasons. IS and 9 observations were recorded. For evaluation of incidence and severity. during the 198283 season 33 plants were selected randomly for each cultivar once at the beginning of each replication. During the 198384 and 198586 seasons, 26 plants were selected. Disease severity was recorded on a scale of 1 to 9 (7) laking inte consideration the extent of stem breaking, defoliation, and pod infection. The percentage of affected tissues was scored as follows: 1 no infection. 2

$15 \% 3=610 \%, 4 \quad 1115 \%, 5$ $1640 \%, 6$. $4150 \%, 7 \quad 5175 \%, 8$ $76100 \%$, and 9 plants killed. First. average disease incidence and severity for each plot were calculated and then the average of each cultivar for three replications.

Disease progress curves were analyzed by a logistic model (1) with the linearized

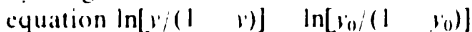
$+r_{1} t$, in which $r_{1}$ is a rate parameter per unit of time, I (apparent infection ratte $r$ ). Disease progress curves for each of the three cultivars for the three seasons were analyred statistically ('Table 1). Weighted mean analyses of variance of intercepts and slopes $(r)$ of the disease progress curves were calculated for comparison of the cultuvars within each season and over three seasons (Table 2).

\section{RESULTS AND DISCUSSION}

Ascochyta blight was severe in three (1982 83, 198384,198586$)$ of the four seasons of studies, as indicated by the high disease severity score for the susceptible cultivar ILC 464 (7.4 8.8, on a 19 scale). No other disease was observed in the experimental plots. Because of extremely low temperatures $(-10 \mathrm{C})$ in the 1984 85 trial, the plants died, and data were not analyzed. In the 1982 83 , 198384 , and 198586 trials, the onset of the disease was identical for ILC 464 and ILC 482. During the 1982 83 season, blight was observed on 3 March in all three cultivars. During the 1983-84 season, blight was observed in ILC 464 and ILC 482 on 24 January and in ILC 3279 on 31 January. During the 1985-86 season, blight appeared in ILC 464 and ILC 482 on 3 April and in ILC 3279 on 10 
April. Except during 1982-83, when final blight incidence differed among the cultivars (Il.C $464=100 \%$. IL.C $482=$ $97 \%$. ILC $3279=11 \%$ ), there were no differences in the other two seasons. The weighted mean analysis of variance on intercepts of the disease progress curves showed significant differences between the genotypes, and the interaction between genotype and season was highly significant (Table 2).

Progress of blight in the three seasons differed significantly between cultivars (Table 1). In each season the blight epidemic progressed rapidly in the susceptible cultivar ILC $464\left(r_{1}=0.69,0.24\right.$. $0.30)$ compared with ILC $482\left(r_{1}=0.17\right.$. $0.16,0.23)$ and IIC $3279\left(r_{1}=0.01,0.01\right.$. 0.02 ). The progress was much more rapid in 1982-83 and 198586 than in 1983-84. Plants were nearly dead in mid-May (Fig. 1). The 3-yr average yield of the susceptible cultivar II.C 464 was 107 $\mathrm{kg} \cdot \mathrm{ha}^{-1}$. No grain yield was produced by II.C 464 in 198283 or 198384

In ILC 482, the disease progress in all the three seasons was slow, and the final disease severity score ( 4 , on a 19 scale) was less than half of ILC 464 (8.3). The $r_{1}$ for 1985-86 was higher (0.29) than for $1982-83(0.17)$ and $1983-84(0.15)$. The 3 -yr average yield of ILC 482 was 1,742

$\mathrm{kg} \cdot \mathrm{ha}^{-1}$. In ILC 3279, during the 198283 season, the disease severity was almost negligible (1.2) and $r_{1}$ was very low $\left(r_{1}\right.$ $=0.031$ ). During the 198384 and 198586 seasons, disease severity was greater (2.4 3.9) and apparent infection rate $r_{1}$ was higher $(0.080 .23)$ but it was much lower than in II.C 482. II.C 3279 yielded $1.816 \mathrm{~kg} \cdot \mathrm{ha}$ ' on the average of the $3 \mathrm{yr}$.

The rate of disease progress for the same cultivar was significantly different in different seasons, and the interaction between cultivar and season was also significant (Table 2). Temperatures that prevailed during different seasons and type of inoculum used in the experiments were responsible for this variation (1). During 19828.3 and 198586 , the minimum temperature was lower than 5 ( $^{\circ}$ until mid-April, whereas during 198485 minimum temperature rose above 5 ( by mid-March. Because minimum $1 \mathrm{em}$ peratures below 5 ( are not compatible with blight infection, disease epidemics were delayed during 198283 and 198485 (10). During 1983 84, although disease appeared early because of warm night temperatures, the blight epidemic was slowed due to a sudden increase in day temperatures $(>20$ () by midMarch.

Table 1. Summary of logistic model statistics used in evaluation of Ascochyta hlight progress in three chickpea cultivars

\begin{tabular}{|c|c|c|c|c|c|}
\hline $\begin{array}{l}\text { Year } \\
\text { Cultivar }\end{array}$ & Intercept \pm SD & $\begin{array}{c}\text { Rate parameter }+ \text { SD } \\
\text { (slope) }\end{array}$ & $\begin{array}{l}R^{2} \\
(\%)\end{array}$ & MSE & $\begin{array}{l}\text { Residual } \\
\text { df }\end{array}$ \\
\hline \multicolumn{6}{|l|}{198283} \\
\hline IIC 464 & $-2.822+0.4 .32$ & $0.6781+0.0855$ & 89.8 & 0.3071 & 6 \\
\hline II.C 482 & $-2.426 \pm 0.0482$ & $0.1730 \pm 0.00955$ & 97.9 & $0 .(k) .3834$ & 6 \\
\hline II.C 3279 & $-2.196+0.0361$ & $0.0293 \pm 0.00927$ & 64.2 & 0.001503 & 4 \\
\hline \multicolumn{6}{|l|}{198384} \\
\hline II.c 464 & $1.66 \pm 0.2660$ & $0.2359 \pm 0.02900$ & 84.5 & 0.2 .343 & 11 \\
\hline II.C $4 \times 2$ & $-1.827+0.1580$ & $0.1450 \pm 0.01730$ & 84.1 & 0.08381 & 12 \\
\hline $11 . C^{\circ} 3279$ & $2.391 \pm 0.0408$ & $0.0798 \pm 0.00445$ & 96.4 & 0.005454 & 11 \\
\hline \multicolumn{6}{|l|}{198586} \\
\hline II. 4464 & $-1.713 \pm 0.5270$ & $0.3879 \pm 0.09360$ & 66.9 & 0.5261 & 7 \\
\hline II.C 482 & $-2.377 \pm 0.52090$ & $0.2869 \pm 0.03720$ & 88.0 & 0.08315 & 7 \\
\hline ILC 3279 & $-2.313+0.1810$ & $0.2269+0.03180$ & 87.7 & 0.06063 & 6 \\
\hline
\end{tabular}

Determined as described in Campbell and Madden (1). $R^{2}-$ Coefficient of determination for agreement between observed and predicted $v$ (incidence or severity of disease); MSF mean square error. All residuals were $\mathrm{OK}$.

Table 2. Weighted analysis of variance on intercepts and slopes of Ascochyta blight disease progress curves in three chickpea cultivars in 1983, 1984, and 1986

\begin{tabular}{|c|c|c|c|c|c|}
\hline \multirow[b]{2}{*}{ Source of variation } & \multirow[b]{2}{*}{ df } & \multicolumn{2}{|c|}{ Intercept } & \multicolumn{2}{|c|}{ Slope } \\
\hline & & SS" & Prob.' & SS & Prob. \\
\hline Year (unadjusted) & 2 & 1.570 & 0.4561 & 54.82 & 0.000 \\
\hline Genotype (adjusted for year) & 2 & 8.906 & 0.0116 & 164.81 & 0.000 \\
\hline Genotype (unadjusted) & 2 & 6.258 & 0.0438 & 175.58 & 0.000 \\
\hline Year (adjusted for genotype) & 2 & 4.219 & 0.1213 & 44.05 & 0.000 \\
\hline Genotype $X$ year & 4 & 27.429 & 0.000 & 41.11 & 0.000 \\
\hline Total & 8 & 37.905 & $\ldots$ & 260.74 & $\ldots$ \\
\hline
\end{tabular}

${ }^{2} \mathrm{SS}=$ The sum of squares is a weighted sum, using as weights the inverse of the variance of the estimates, and approximately follows a chi-square distribution with the indicated degrees of freedom.

${ }^{b}$ Prob. is the probability of obtaining a greater $F$ value.
The lower disease incidence in 11. 3279 during 19828.3 in comparison wit the other seasons resulted from the typ of infested debris used for inoculatior The diseased debris used in the 19828 season was from a single susceptible cul tivar. II C 1929, incoulated with a singl isolate (Tel Hadya isolate, later desig nated as race 3) (6). In the 198384 ant 198586 seasons, the infested debris user for inoculation was from a blight-screen ing nursery in which several germ plasr accessions and breeding lines were in oculated with a mixture of isolates a 4. rabiet. The increased blight incidenct in II. 3279 during the 198.384 anc 1985 86 seasons thus could have resulter from the increased frequency of isolate of .1. rabiei in the inoculum that wer able to infect it. The same factor ma have been responsible for the increase severity of blight in the later two scason: compared with the first season.

If the time of blight appearance i considered the beginning of the epidemi (13), during all three seasons the epi demic started in 11 ( 482 at the same time as in susceptible cultivar 11 . 464 hut it progressed more slowly because of the low infectoon rate. By mid-May when the crop reached maturity, the amount of discase in $11 . C^{\prime} 482$ was lese than half that in the susceptible line, and consequently yield loss was lower. This result is in agreement with the horizontal resistance concept of Vanderplank (13). in which horizontal resistance does not delay the start of an epidemic but only reduces the rate of progress.

Blight incidence in II.( 3279 during 198283 was very low, which indicated reduction of initial inoculum. In (wo out of three seasons (1982 83 and 1983 84). blight epidemic in IL. ( 3279 was delayed by 7 days. However, if the start of the epidemic is considered in relation to the logarithmic phase of the disease (13). there was nodelay in the start of epidemic in II. 3279 compared with the other two cultivars. During the 198283 season, the epidemic did not progress. During the 198384 and 198586 seasons, the epidemic was drastically slowed down. Thus, except for the reduction in initial inoculum during the 19828.3 season, which is a characteristic of vertical re sistance, resistance in II.C 3279 was in conformity with the horizontal resistance concept of Vanderplank (13).

ILC 482 and ILC 3279 were widely tested for Ascochyta blight resistance and yield in the Mediterranean region in the winter season. ILC 3279 was tesistant to Ascochyta blight at most locations (12). In ILC 482, which was resistant to blight at ICARDA in earlier years, patches of dead plants were observed during 1981 (3). The A. rabiel isolate from these ILC 482 dead plants was later found to be of a different race than the one found earlier (6). Under field conditions, ILC 482 usually does nol 

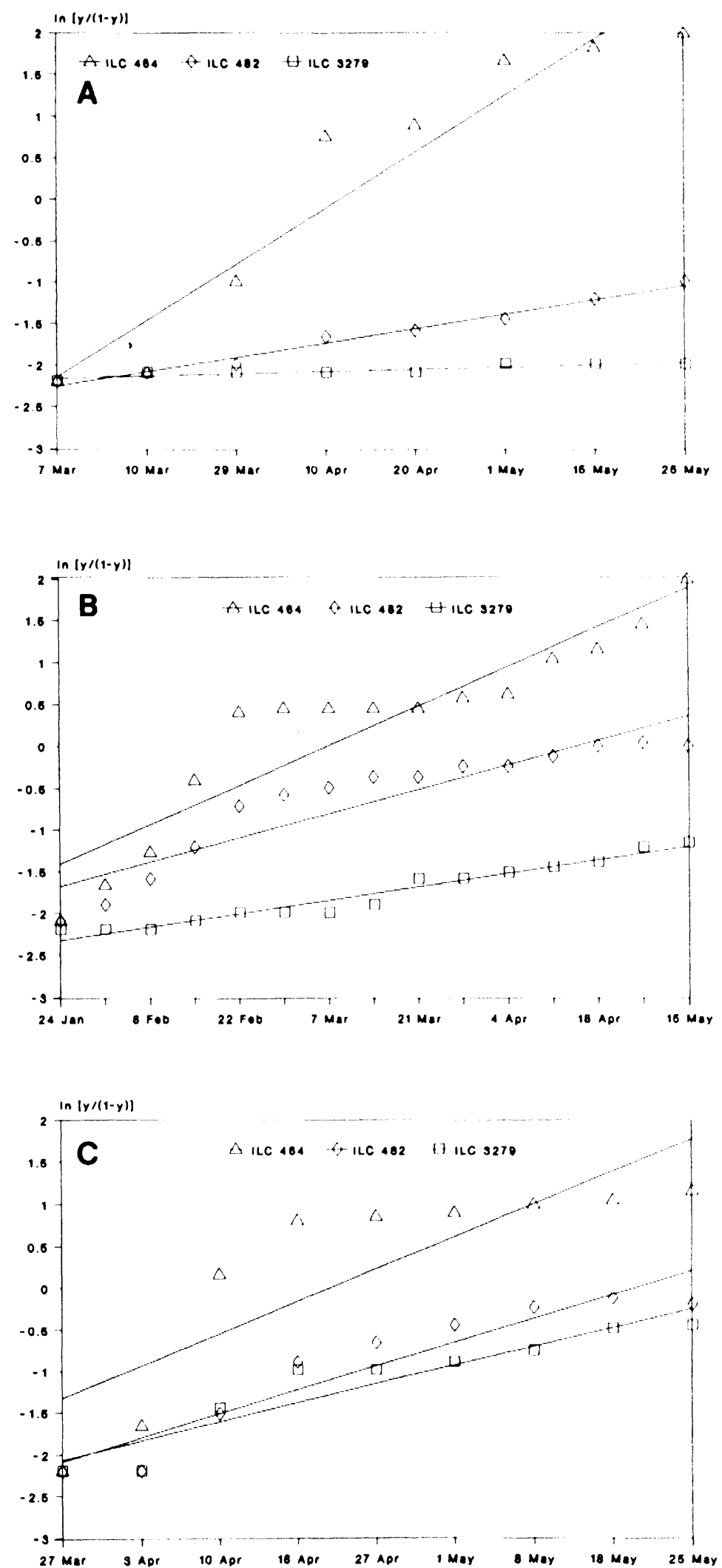

Fig. 1. Progress of Ascochyta blight in three chickpea cultivars at the International Center for Agricultural Research in the Dry Areas (ICARDA), Aleppo, Syria, in (A) 1982-83, (B) 198384 , and (C) 1985.86. show complete susceptibility to the new race, but it has disease severity scores of 56 on a 19 scale compared with scores of 34 against the old race. In a situation where the susceptible cultivar was killed, the yield of II C 482 averaged $1.7(0) \mathrm{kg} \cdot \mathrm{ha}$ 'over three seasons in comparison with $2,300 \mathrm{~kg} \cdot \mathrm{ha}^{\prime}$ ' in plots completcly protected against blight (9).

II C 482 has been released in Algeria. France. Iordan. Lebanon. Morocco. Syria, and Turkes and IIC 3279 in Algeria, Cyprus, Italy, Jordan, Syria, and Tunisia for cultivation in the winter season; both are maintaining their resistance. In Syria alone, the estimated area of winter cultivation of II.C 482 is $40,000)$ ha. Thus the rate-reducing resistance in these lines is useful over a wider geographic area. These are the first chick pea cultivars resistant to Ascochyta blight that have heen released in more than one country. Because these cultivars demonstrate rate-reducing resistance against a mixture of isolates and an ability 10 perform well in a large number of countries against the pathogen $A$. rabie', their resistance may be more stable than the resistance of previous cultivars.

\section{IITERATIRF. (ITFI)}

I (amphell, ( I and Matden, I V 1990 Pages If) 202 in Imioduction to Plant Discase I pidemolog) John Wiley \& Sons, New York. Hawten, (; C and Singh, K H 1984 Pruspects and potental of winter sowing of chickpeas in the Medilertanean region Pages 7-16 in. Ascochyta Blight and Winter Sowing of Chokpeas $M$ ( Saxerla and $K \mathbf{B}$ Singh, eds Martinus Niphofl I) W Junk Publishers, Ihe Hague

1 (IARI)A 19KI Reporl of wolk on Ascochyta blight of chichpeat, lYK() 81 . I( ARI)A. Aleppo. Syria $71 \mathrm{pp}$

Katusar, A (; 1965 I puphylology of recent cpepleytotics of gram hlight in West Paksstan Pakistan J Agric So 2 185 19:

Nene, Y I and Reddy, M V 19K7 Chickpea descases and thes control Pages 233-270 in: the Chockpea M C Saxena and K. B. Singh, eds ( A B International, Wallingtord, U.K

6) Reddy. $M V$, and Kahbahch, $S$ 1985. Pathogen vamability in Ascochysu rabres in Syria and I chanon Phylopathol Mediter 24.265-266 Reddy. M. V., and Singh. K. B. $19 \times 4$ Fvaluation of a world collection of chickpea germ plasm accessons for resistance to Ascochyta blight Plant I) $68.9(5)-901$

$x$ Reddy, M V. and Singh, K B. 1990) Management of Ascochyta blight of chickpea through integration of host plant wolerance and foliar spraying of chlorothatonil. Indian J. Plant Prot. 18:65-69.

9 Reddy, M V and Singh, K. B. 1990. Relationship between Ascochyta blight severity and yield loss in chickpea and identification of resstant lines. Phytopathol. Mediterr. 29:32-38.

10. Reddy, M V., and Singh, K. B. 1991 Relalionship between temperature, relative humidity and Ascochyta blight development in wintersown chickpea in Syria. Phytopathol. Mediterr. 29:159-1(6)

1I. Singh, K. B., and Reddy. M. V. 1991. Advances in disease-resislance breeding in chickpea. Adv. Agron 45:191-222.

12. Singh, K. B., Keddy, M. V., and Nene, Y. I. 1984. International testing of chickpeas for resistance to Ascochyta blight. Plant Dis. 68: $782-784$

13. Vanderplank, J, E. 1963. Plant Diseases: Epidemics and Control. Academic Press, New York. 349 pp. 